\title{
Additional protein intake limits weight regain after weight loss in humans
}

\author{
Manuela P. G. M. Lejeune*, Eva M. R. Kovacs and Margriet S. Westerterp-Plantenga \\ Department of Human Biology, Maastricht University, P.O. Box 616, 6200 MD Maastricht, The Netherlands
}

(Received 28 January 2004 - Revised 7 July 2004 - Accepted 21 September 2004)

\begin{abstract}
Since long-term weight maintenance (WM) is a major problem, interventions to improve WM are needed. The aim of the study was to investigate whether the addition of protein to the diet might limit weight regain after a weight loss of 5-10\% in overweight subjects. In a randomised parallel study design, 113 overweight subjects (BMI 29.3 (SD 2.5) $\mathrm{kg} / \mathrm{m}^{2}$ ); age 45.1 (SD 10.4) years) followed a very-lowenergy diet for 4 weeks, after which there was a 6-month period of WM. During WM, subjects were randomised into either a protein group or a control group. The protein group received $30 \mathrm{~g} / \mathrm{d}$ protein in addition to their own usual diet. During the very-low-energy diet, no differences were observed between the groups. During WM, the protein group showed a higher protein intake $(18 \% v .15 \%$; $P<0.05$ ), a lower weight regain $(0.8 v .3 .0 \mathrm{~kg} ; P<0.05$ ), a decreased waist circumference $(-1.2$ (SD 0.7$) v .0 .5(\mathrm{SD} 0.5) \mathrm{cm} ; P<0.05)$ and a smaller increase in respiratory quotient $(0.03(\mathrm{SD} 0.01) v .0 .070 .01 ;(\mathrm{SD} /) P<0.05)$ compared with the control group. Weight regain in the protein group consisted of only fat-free mass, whereas the control group gained fat mass as well. Satiety in the fasted state before breakfast increased significantly more in the protein group than in the control group. After 6 months follow-up, body weight showed a significant group $\times$ time interaction. A protein intake of $18 \%$ compared with $15 \%$ resulted in improved WM in overweight subjects after a weight loss of $7.5 \%$. This improved WM implied several factors, i.e. improved body composition, fat distribution, substrate oxidation and satiety.
\end{abstract}

Substrate oxidation: Weight maintenance: Body composition: High protein

A common treatment for obesity is weight reduction. Although short-term weight loss programmes have proved to be successful, long-term weight maintenance (WM) is a major problem (Kramer et al. 1989; Wadden et al. 1994; Pasman et al. 1997a,b; Westerterp-Plantenga et al. 1998). Successful weight maintenance is of importance for lowering risk factors for cardiovascular and other diseases (Goldstein, 1992; Wing et al. 1992; Van Gaal et al. 1997). To improve the metabolic profile, it is not necessary to achieve the ideal body weight: a weight reduction of $5-10 \%$ is often sufficient to induce a clinically relevant effect (Goldstein, 1992). To preserve these beneficial effects of weight reduction, an improvement in long-term WM is necessary.

Pasman et al. (1999) showed that weight regain was slower when the body composition of the weight regained consisted of a greater fat-free mass (FFM) due to physical activity. We hypothesise that weight regain may be limited if the inevitable increase in body weight consists of a larger FFM, for instance achieved by the consumption of an appropriate substrate. For this, we suggest an increased protein intake, because of its potential to increase FFM (Jean et al. 2001). Furthermore, it is known that, of all the macronutrients, protein seems to be the most satiating. Protein consumption suppresses short-term food intake more than that of fats or carbohydrates, and even more than is expected from its energy content alone (Anderson 1994). Several studies have shown that a high-protein lunch decreases later food intake more than a lunch low in protein (Booth et al. 1970; Barkeling et al. 1990; Latner \& Schwartz, 1999). Westerterp-Plantenga et al. (1999) showed an increased satiety effect of a high-protein diet despite similar energy intake. Finally, protein has also been shown to have low energy efficiency during overfeeding (Dulloo \& Jacquet, 1999; Stock, 1999), a situation that is comparable to a weight regain situation. Although the effect of dietary protein has been examined in weightloss studies (Skov et al. 1999; Dumesnil et al. 2001; Layman et al. 2003), the effect of additional protein intake on WM has not yet been studied. The aim of this study was to investigate whether the addition of protein to the diet might limit weight regain after a weight loss of $5-10 \%$ in moderately overweight subjects.

\section{Subjects and methods}

Subjects

One hundred and forty moderately overweight male and female subjects (BMI $25-35 \mathrm{~kg} / \mathrm{m}^{2}$, age $18-60$ years) were recruited for this study by advertisements in local

\footnotetext{
Abbreviations: FFM, fat-free mass; FM, fat mass; PAL, physical activity level; REE, resting energy expenditure; RQ, respiratory quotient; TBW, total body water; TEE, total energy expenditure; TFEQ, Three Factor Eating Questionnaire; VLED, very-low-energy diet; WM, weight maintenance.

* Corresponding author: Ms M. P. G. M. Lejeune, fax +31 43367 09 76, email M.Lejeune@HB.Unimaas.NL
} 
newspapers. They underwent a medical screening. All the subjects were in good health, were non-smokers, were not using medication and were at most moderate alcohol users. A written informed consent was obtained from all the participants. The Medical Ethics Committee of the Academic Hospital in Maastricht approved the study. Twenty subjects did not start the study due to relocation, a change of job or an inability to fulfil the schedule with visits to the university. Intention-to-treat applied for 120 subjects. During the first week, seven subjects dropped out because of difficulty maintaining the very-low-energy diet (VLED). They had been meant to participate in the additional-protein group. Their baseline characteristics did not affect the averages of the baseline measurements of the treatment group. Thus, 113 subjects completed the study. Subject characteristics are shown in Table 1.

\section{Experimental design}

After the subjects' baseline characteristics had been determined, they were divided into two similar groups, stratified for gender, BMI, age, eating behaviour (Three Factor Eating Questionnaire (TFEQ); Stunkard \& Messick, 1985; Westerterp-Plantenga et al. 1999) and resting energy expenditure (REE). Both groups followed a VLED intervention for 4 weeks in order to initiate weight loss. After this weight loss period, a WM period of 6 months followed. Subjects in both groups visited the university six times. During these visits, the measurements were carried out as described in the Measurements section below. Moreover, the subjects were asked by a dietitian how they felt, how they considered taking part in the study and whether they had any specific questions. Furthermore, dietary counselling was provided upon request for all subjects.

One of the groups was provided with additional protein (protein group, $n$ 53), while the other group did not receive this additional protein (control group, $n$ 60). Since, similar to previous meal-replacement studies (Ditschuneit et al. 1999; Flechtner-Mors et al. 2000; Rothacker 2000; Ashley et al. 2001; Allison et al. 2003), no placebo was used for this control group, we included repeated measurements of dietary restraint to check whether additional dietary protein would affect attitudes towards eating differently. After 6 months of WM, the additional protein intake was stopped. Six months after WM, all the subjects were asked to return to the university for a follow-up measurement of body weight. For this measurement, thirty-one subjects in the protein group and thirty-nine subjects in the control group returned.

\section{Measurements}

The following measurements were executed to determine subject characteristics (Table 1).

Body weight and BMI. Body weight was measured on a digital balance (model 707, Seca, Hamburg, Germany; weighing accuracy of $0.1 \mathrm{~kg}$ ) with subjects in their underwear, in a fasted state and after voiding their bladder. Height was measured using a wall-mounted stadiometer (model 220, Seca, Hamburg, Germany).
BMI was calculated as body weight divided by height ${ }^{2}$ $\left(\mathrm{kg} / \mathrm{m}^{2}\right)$.

Waist:hip ratio. The distribution of fat was investigated by measuring the waist and hip circumferences, and then calculating the waist:hip ratio. The waist circumference was measured at the site of the smallest circumference between the rib cage and the iliac crest, with the subjects standing. The hip circumference was measured at the site of the largest circumference between the waist and the thighs. The waist:hip ratio was calculated by dividing the waist circumference by the hip circumference.

Body composition. Total body water (TBW) was measured using the ${ }^{2} \mathrm{H}_{2} \mathrm{O}$ dilution technique (Schoeller et al. 1980; Van Marken Lichtenbelt et al. 1994). In the evening, the subjects collected a background urine sample and then ingested a dose of ${ }^{2} \mathrm{H}$-enriched water $\left({ }^{2} \mathrm{H}_{2} \mathrm{O}\right)$, after which they refrained from consuming fluid and food. The following morning, a urine sample from the second voiding was collected between $08.00 \mathrm{~h}$ and $10.00 \mathrm{~h}$. The concentration of ${ }^{2} \mathrm{H}$ in the urine samples was measured using an isotope ratio mass spectrometer (Micromass Optima, Manchester, UK). TBW was obtained by dividing the measured ${ }^{2} \mathrm{H}$ dilution space by 1.04 (Schoeller et al. 1980). FFM was calculated by dividing the TBW by the constant hydration factor 0.73 , which can be used for adult subjects (Schoeller, 1996). The weight loss and weight maintenance periods were long enough to establish a stable hydration of FFM. Fat mass (FM) was calculated by subtracting FFM from body weight. FM expressed as a percentage of total body mass is body fat percentage.

Attitude towards eating. To determine whether attitude towards food intake changed during the experiment, a Dutch translation of the TFEQ was used (Stunkard \& Messick, 1985; Westerterp-Plantenga et al. 1999). The first factor of the TFEQ (F1) measures cognitive restrained eating: control of food intake by thought and will-power. The second factor (F2) represents disinhibition: an incidental inability to resist eating cues, or inhibition of dietary restraint, and emotional eating. The third factor (F3) examines the subjective feeling of general hunger.

In addition, the Herman-Polivy questionnaire was used to determine the frequency of dieting (Herman \& Polivy, 1980).

Post-absorptive appetite profile. To determine the postabsorptive appetite profile, hunger and satiety were rated on anchored $100 \mathrm{~mm}$ visual analogue scales in the morning before breakfast.

Blood parameters. A fasting blood sample of $10 \mathrm{ml}$ was taken and mixed with EDTA to prevent clotting. Plasma was obtained by centrifugation (at $3000 \mathrm{U} / \mathrm{min}$ for $10 \mathrm{~min}$ at $4{ }^{\circ} \mathrm{C}$ ), frozen in liquid nitrogen and stored at $-80^{\circ} \mathrm{C}$ until further analysis. Plasma glucose concentrations were determined using the hexokinase method (Glucose HK 125 kit; ABX diagnostics, Montpellier, France). The Wako NEFA C-kit (Wako Chemicals, Neuss, Germany) was used to determine free fatty acid concentrations. Insulin concentrations were measured using the RIA-kit (Insulin RIA-100; Kabi-Pharmacia, Uppsala, Sweden). The glycerol kinase method was used to determine glycerol concentrations (Boehringer Mannheim GmbH, Mannheim, 

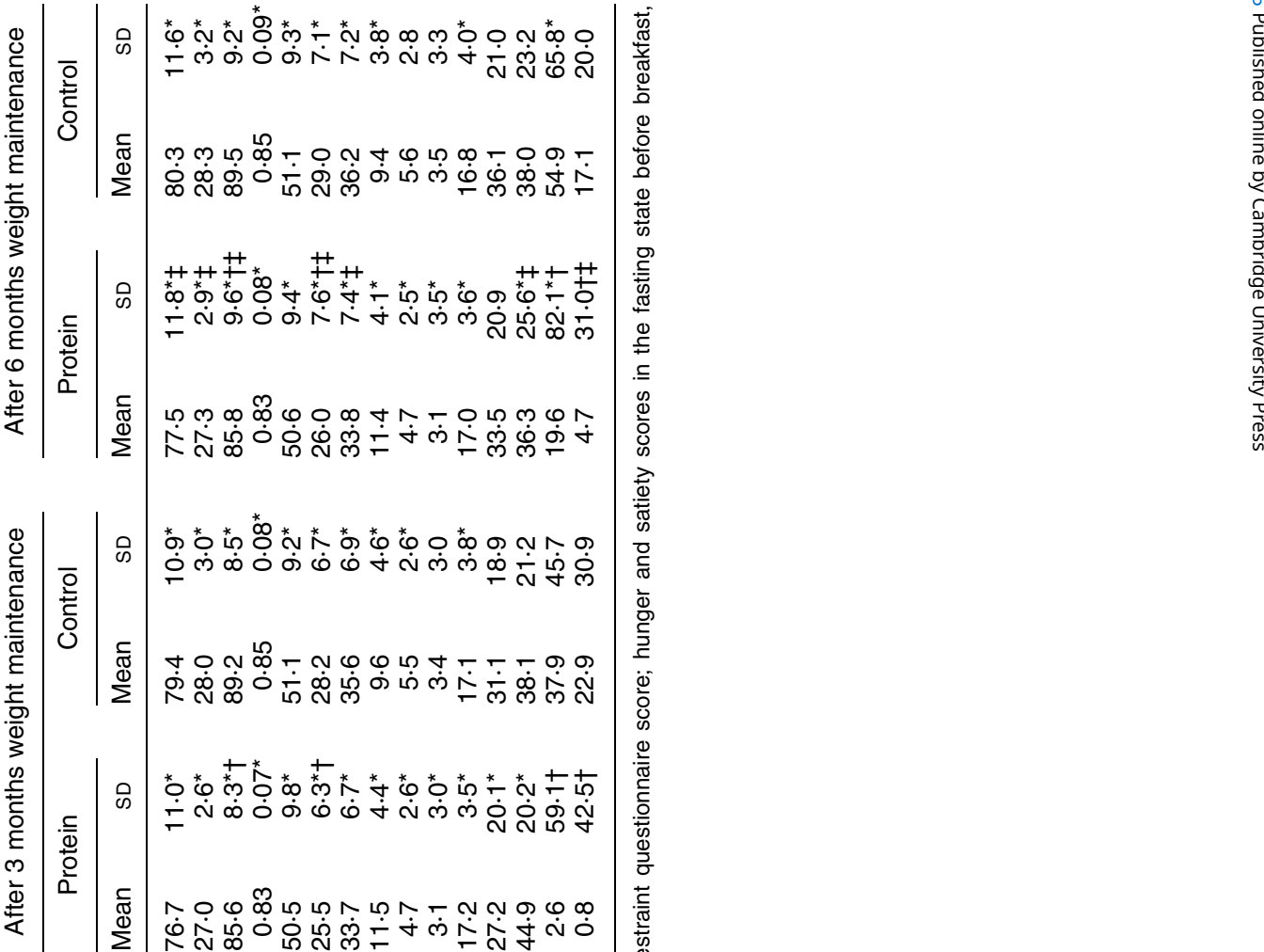

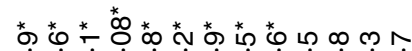

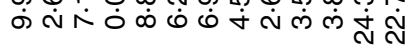

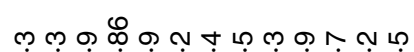

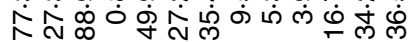

大ั

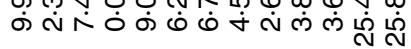

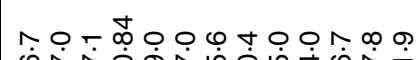

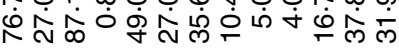

†

山่人்

A t

ஜ வ்

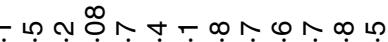

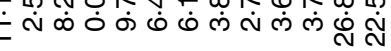

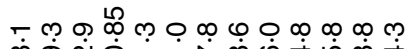


Germany). Triacylglycerol was measured using the GPOtrinder kit (Sigma Diagnostics Inc., St Louis, MO, USA). The $\beta$-hydroxybutyrate dehydrogenase method (Sigma Diagnostics Inc., St Louis, MO, USA) was used to determine $\beta$-hydroxybutyrate concentration. Leptin concentrations were measured using the human leptin RIA-kit (Linco Research Inc., St Charles, MO, USA).

Adverse events. Adverse events during treatment were recorded and the severity and outcome specified.

REE and substrate oxidation. In a random subset of subjects ( $n$ 75), REE and substrate oxidation were measured by means of an open-circuit ventilated hood system. REE was measured in the morning with subjects in a fasted state while lying supine for $30 \mathrm{~min}$. Gas analyses were performed by a paramagnetic oxygen analyser (type 500A, Servomex, Crowborough, Sussex, UK) and an IR carbon dioxide analyser (type 500A, Servomex, Crowborough, Sussex, UK), similar to the analysis system described by Schoffelen et al. (1997). Calculation of REE was based upon the Weir's formulas (Weir, 1949). Respiratory quotient (RQ) was calculated as $\mathrm{CO}_{2}$ produced $/ \mathrm{O}_{2}$ consumed.

Physical activity. The same subset of subjects who underwent metabolic testing was used to measure physical activity level (PAL). PAL was determined using a uniaxial accelerometer (CSA, CSAB, Inc. Stamford, CT, USA.) (Ekelund et al. 2000), or a tri-axial accelerometer for movement registration (Tracmor Maastricht University, Maastricht, The Netherlands.) (Goris et al. 2001), during 1 week. Subjects wore the CSA or Tracmor during waking hours on a belt at waist level on their back. The different accelerometers were randomised over the two groups. Half the subjects in the protein group and the control group received the CSA, the other half received the Tracmor. Subjects received the same accelerometer every time.

PAL was calculated using the following equations:

CSA (Ekelund et al. 2000): PAL

$$
=(0.000001379 \times(\text { counts } / \text { day } \times 5))+1.113
$$

Tracmor (Goris et al. 2001): TEE

$$
=-1.259+(1.552 \times \mathrm{REE})+(0.076 \times \text { counts } / \mathrm{min})
$$

$$
\mathrm{PAL}=\mathrm{TEE} / \mathrm{REE}
$$

in which TEE is total energy expenditure $(\mathrm{MJ} / \mathrm{d})$ and REE is resting energy expenditure (MJ/d).

Protein intake. Compliance with additional protein intake was checked by taking $24 \mathrm{~h}$ urine samples after 3 months WM and analysing these for nitrogen. Energy intake from protein was calculated from the $24 \mathrm{~h}$ nitrogen output according to the formula of Isaksson (1980):

$$
\begin{aligned}
& \text { Protein intake }(\mathrm{g}) \\
& \quad=(\text { nitrogen output in } 24 \mathrm{~h} \text { urine }(\mathrm{g} / \mathrm{d})+2 \mathrm{~g}) \times 6.25
\end{aligned}
$$

Energy intake and energy efficiency. Energy intake was calculated as TEE plus energy storage (ES). Energy storage was calculated from the composition of the energy stored. A figure of $30 \mathrm{MJ}$ per kilogram body weight gain (Pullar
\& Webster, 1977) was taken for the usual energy storage of FM and FFM (A). If body weight gain consisted of only FFM while FM decreased, $52 \mathrm{MJ} / \mathrm{kg}$ FFM gain (Pullar \& Webster, 1977) and 30 MJ/kg FM loss were used (B).

$$
\text { (A) } \begin{aligned}
\mathrm{ES} \quad(\mathrm{MJ} / \mathrm{d})= & (\Delta \text { body weight }(\mathrm{kg}) \times 30) / \text { number } \\
& \text { of days } \\
\text { (B) } \mathrm{ES}(\mathrm{MJ} / \mathrm{d})= & ((\Delta \mathrm{FFM}(\mathrm{kg}) \times 52)-(\Delta \mathrm{FM}(\mathrm{kg}) \times 30)) / \\
& \text { number of days }
\end{aligned}
$$

To see whether a higher percentage of energy ingested as protein in the diet could lower the energy efficiency, which is known already as the 'Stock' hypothesis (Dulloo \& Jacquet, 1999; Stock, 1999), we used the following equation to calculate energy efficiency (Eeff):

$$
\begin{aligned}
\text { Eeff }(\mathrm{kg} / \mathrm{MJ})= & \text { body weight regain }(\mathrm{kg}) /(\mathrm{EI}(\mathrm{MJ} / \mathrm{d}) \\
& \times \text { number of days })
\end{aligned}
$$

\section{VLED period}

The VLED provided $2 \cdot 1 \mathrm{MJ} / \mathrm{d}$ (carbohydrate-protein-fat 42:44:14 energy percentage) (Modifast, Novartis Nutrition, Breda, The Netherlands) and was supplied in three sachets daily that were dissolved in water to obtain a milk shake, pudding, soup or muesli. Vegetables and fruit were allowed in addition to Modifast. The aim was a body weight loss of at least $4 \mathrm{~kg}$ over 4 weeks.

\section{WM period}

After the VLED period, the WM period started, in which all subjects were allowed to eat their habitual diet again. During the WM phase, the subjects in the protein group received $30 \mathrm{~g}$ additional protein per day. This was provided as a sachet of pure protein (protein source calcium caseinate, $1.4 \%$ calcium) per day to be dissolved in water, giving rise to a vanilla-flavoured drink. The protein drink contained no carbohydrate or fat. Subjects were required to consume the protein drink at lunch or in the afternoon. In this way, we aimed at an energy intake comprising $18-20 \%$ protein/d, depending on the subject's usual protein intake.

\section{Data analysis}

Data are presented as mean and standard deviation (SD). A two-factor repeated measures ANOVA was carried out to determine possible differences between the protein and control groups in all measured parameters over time. When appropriate, a factorial ANOVA was used for analysing differences between the two groups. Post hoc analyses were made with the Scheffe F-test. A $P$ value $<0.05$ was regarded as statistically significant. Statistical procedures were performed using Statview SE + Graphics (Abacus Concepts, Berkeley, CA, USA).

\section{Results}

The effects did not differ between men and women so data from both genders were analysed together. No adverse events occurred. Subjects continuously reported that they 
felt positive about taking part in the study. They confirmed that ample attention was given to their questions.

\section{VLED period}

During the VLED period, the changes described below occurred, which did not differ between the subsequent protein and control groups (Table 1). Subjects lost a significant amount of body weight, i.e. $6 \cdot 3$ (SD $2 \cdot 0) \mathrm{kg}$, or $7 \cdot 5$ (SD 2.0$) \%$ of their original body weight $(P<0 \cdot 0001)$. The mean change in body weight for both groups over time is shown in Fig. 1. This consisted of 4.0 (SD 1.7) $\mathrm{kg}$ FM and 2.3 (SD 1.7) kg FFM. Waist circumference was also significantly reduced over time. Attitude towards eating showed some significant changes over time (Table 1). Cognitive restraint (F 1, TFEQ) increased significantly; disinhibition (F 2, TFEQ) and general hunger scores (F 3, TFEQ) decreased during weight loss (Table 1). REE and RQ decreased during weight loss (Table 2). TEE decreased in both groups, but this only reached significance in the control group. Fasting blood glucose, insulin, triacylglycerol and leptin levels showed a significant decrease with weight loss, and $\beta$-hydroxybutyrate, glycerol and free fatty acids showed a significant increase with weight loss (Table 3).

\section{WM period}

Compliance with the additional protein was shown by a higher amount of nitrogen in $24 \mathrm{~h}$ urine in the protein group compared with the control group (14.3 (SD 3.5) g/d v. $11.2(\mathrm{SD} 3.5) \mathrm{g} / \mathrm{d} ; P<0.05)$. The protein intake in the protein group was 101.7 (SD 22.2) g/d, which was significantly higher than the 82.7 (SD 22.0) $\mathrm{g} / \mathrm{d}$ in the control group $(P<0 \cdot 05)$. When expressed as percentage of energy intake from protein, significant differences persisted, with $18 \%$ in the protein group and $15 \%$ in the control group $(P<0.05)$.

During WM, percentage body weight regain, as well as rate of regain, was significantly lower in the protein group than the control group (Table 1; Fig. 2). The net percentage body mass lost after the WM period compared

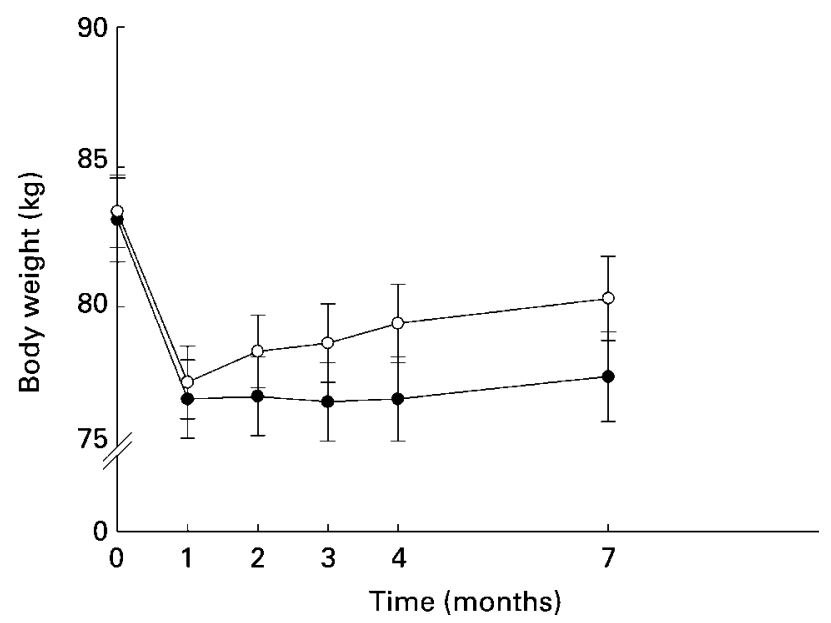

Fig. 1. The change in body weight over time for the protein group $(\bullet)(n 53)$ and the control group (o) (n 60). Values are means with standard deviations of the mean shown by vertical bars.

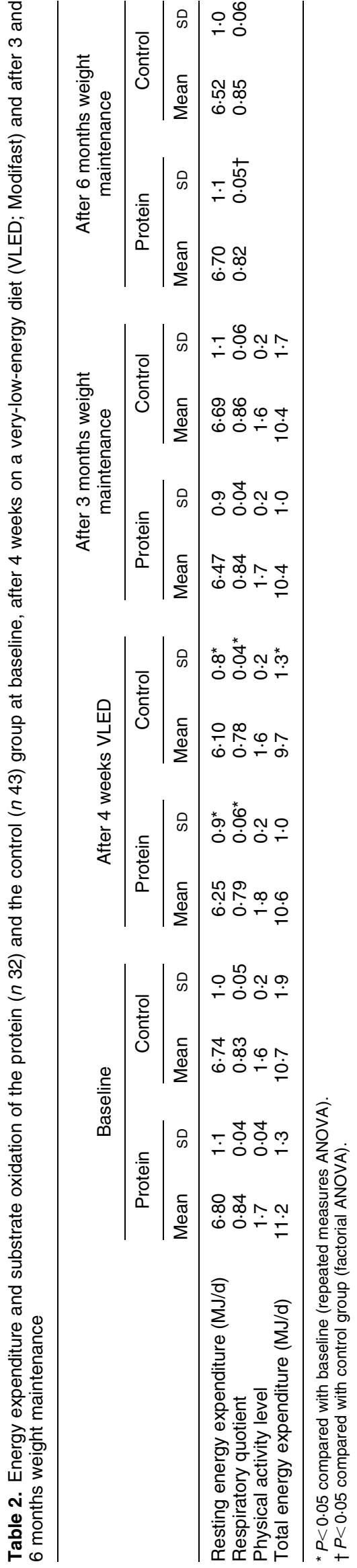


Table 3. Fasting blood-parameters of the protein ( $n$ 32) and the control $(n 43)$ group at baseline, after 4 weeks on a very-low-energy diet (VLED; Modifast) and after 3 months weight maintenance

\begin{tabular}{|c|c|c|c|c|c|c|c|c|c|c|c|c|}
\hline & \multicolumn{4}{|c|}{ Baseline } & \multicolumn{4}{|c|}{ After 4 weeks VLED } & \multicolumn{4}{|c|}{ After 3 months weight maintenance } \\
\hline & \multicolumn{2}{|c|}{ Protein } & \multicolumn{2}{|c|}{ Control } & \multicolumn{2}{|c|}{ Protein } & \multicolumn{2}{|c|}{ Control } & \multicolumn{2}{|c|}{ Protein } & \multicolumn{2}{|c|}{ Control } \\
\hline & Mean & SD & Mean & SD & Mean & SD & Mean & SD & Mean & SD & Mean & SD \\
\hline Glucose $(\mathrm{mmol} / \mathrm{l})$ & 5.5 & 0.5 & $5 \cdot 6$ & 1.0 & $5 \cdot 2$ & $0.4^{*}$ & $5 \cdot 2$ & $0.6^{*}$ & 5.4 & 0.5 & $5 \cdot 3$ & $0.6^{*}$ \\
\hline Insulin $(\mu \mathrm{U} / \mathrm{ml})$ & $10 \cdot 8$ & $5 \cdot 3$ & $9 \cdot 9$ & 3.5 & $6 \cdot 7$ & $2 \cdot 4^{*}$ & $7 \cdot 0$ & $3.3^{*}$ & $7 \cdot 9$ & $6 \cdot 0^{*}$ & 8.4 & $3 \cdot 9^{*}$ \\
\hline$\beta$-Hydroxy butyrate $(\mu \mathrm{mol} / \mathrm{l})$ & 233.0 & $70 \cdot 0$ & 248.8 & 87.9 & $537 \cdot 0$ & $272.9^{*}$ & 483.6 & $348 \cdot 5^{*}$ & 256.4 & $87 \cdot 3$ & 255.2 & 89.4 \\
\hline Glycerol $(\mu \mathrm{mol} / \mathrm{l})$ & 93.3 & 38.1 & 94.1 & $35 \cdot 2$ & $109 \cdot 6$ & $53 \cdot 0^{*}$ & $104 \cdot 3$ & $69 \cdot 7^{*}$ & 90.7 & $36 \cdot 2$ & $86 \cdot 5$ & 34.3 \\
\hline Free fatty acids $(\mu \mathrm{mol} / \mathrm{l})$ & $300 \cdot 6$ & $122 \cdot 1$ & 323.6 & 145.5 & $441 \cdot 1$ & $188 \cdot 5^{\star}$ & $402 \cdot 4$ & $226 \cdot 8^{*}$ & 297.6 & $151 \cdot 7$ & 273.8 & $134 \cdot 2$ \\
\hline Triacylglycerol $(\mu \mathrm{mol} / \mathrm{l})$ & $1 \cdot 2$ & 0.6 & 1.6 & 0.9 & 0.9 & $0.3^{*}$ & 1.0 & $0.5^{*}$ & 1.0 & 0.5 & 1.3 & 0.7 \\
\hline Leptin $(\mu \mathrm{g} / \mathrm{l})$ & $21 \cdot 7$ & $10 \cdot 7$ & $22 \cdot 7$ & 11.8 & 8.7 & $5 \cdot 7^{*}$ & $10 \cdot 7$ & $7 \cdot 1^{*}$ & $15 \cdot 8$ & $10 \cdot 4^{\star} \dagger \ddagger$ & 20.4 & 11.9 \\
\hline
\end{tabular}

${ }^{\star} P<0.05$ compared with baseline (repeated measures ANOVA).

$\dagger P<0.05$ compared with control group (factorial ANOVA).

$\ddagger P<0.05$ interaction treatment $\times$ time (two-factor repeated measures ANOVA).

with baseline was significantly higher in the protein group than the control group (6.7 (SD 7.2) \% v. 3.8 (SD 4.8)\%; $P<0.05)$. The protein group showed a decrease in waist circumference during WM, whereas the control group showed an increase $(-1.2(\operatorname{SD} 0.7) \mathrm{cm} \quad v .0 .5(\operatorname{SD~} 0.5)$ $\mathrm{cm} ; \quad P<0.05)$. FFM stayed significantly lower during WM compared with baseline in both groups. FM in the protein group continued to decrease during WM, while FM increased in the control group $(-0.9$ (SD 0.7) $\mathrm{kg} v$. 1.7 (SD 0.4) kg; $P<0.005$ ) (Fig. 3). Cognitive restraint scores stayed significantly higher during WM compared with baseline in both groups. No differences were seen in the change in cognitive restraint during the study between the groups. Disinhibition stayed significantly lower in both groups, and general hunger decreased in both groups. Satiety in the fasted state before breakfast increased significantly during WM in the protein group but not in the control group (Table 1). The increase in satiety was significantly higher in the protein group than the control group. The hunger scores in the fasted state before breakfast did not change over time in either group.

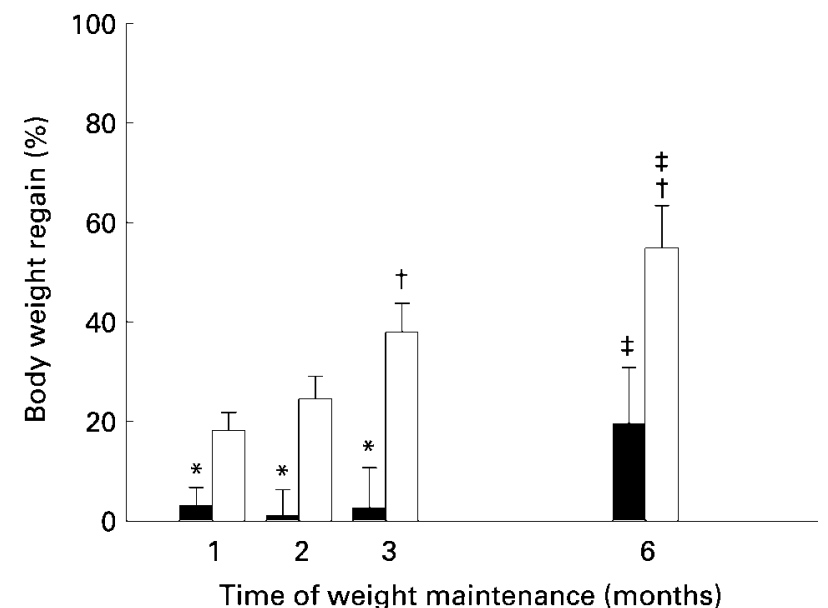

Fig. 2. The weight regain during weight maintenance (expressed as percentage of the weight loss) for the protein (ם) ( $n$ 53) and the control $(\square)(n 60)$ groups. Values are means with standard deviations of the mean shown by vertical bars. ${ }^{*} P<0.05$ compared with control group, $\dagger P<0.05$ compared with 1 month weight maintenance, $\ddagger P<0.05$ compared with 2 months weight maintenance.
REE returned to almost baseline values in both groups during WM (Table 2). To assess possible differences in REE adjusted for FFM between groups, we analysed the residuals of the regression of REE $v$. FFM. The residual analysis showed no significant group $\times$ time interaction. The increase in RQ during WM was significantly smaller
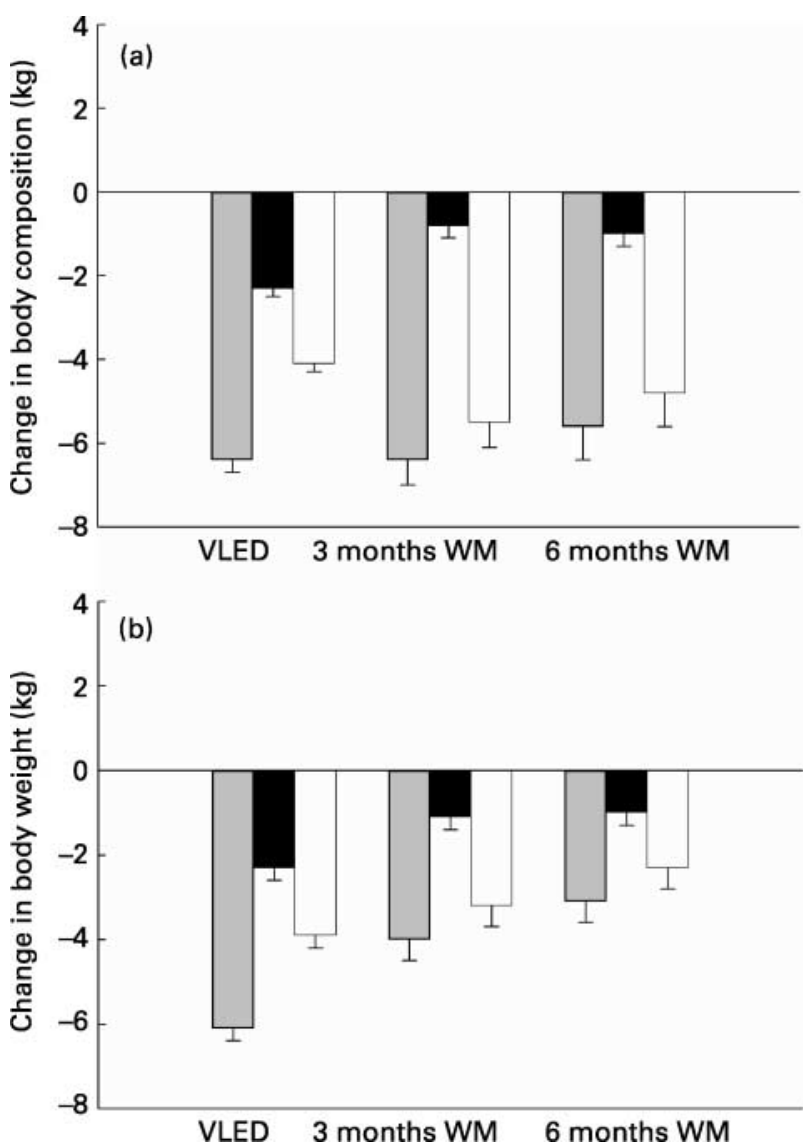

Fig. 3. The changes in body weight $(\square)$, fat-free mass $(\square)$ and fat mass ( $\square$ ) for (a) the protein group ( $n$ 53) and (b) the control group $(n 60)$ during the study compared with baseline. Values are means with standard deviation of the mean shown by vertical bars. VLED, change after the very-low-energy diet period; 3 months WM, change after 3 months weight maintenance; 6 months WM, change after 6 months weight maintenance. 
in the protein group than the control group (0.03 (SD 0.01) v. 0.07 (SD 0.01$) ; P<0.05$ ), indicating a smaller decrease in fat oxidation in the protein group than in the control group. The increase in RQ was not related to weight regain $(P>0 \cdot 05)$. No changes in PAL were seen over time and between groups (Table 2). A trend for a lower energy efficiency of the protein group than the control group was found after 6 months WM $\left(3.0 \times 10^{-4}(\mathrm{SD} 0.003) \mathrm{kg} / \mathrm{MJ}\right.$ v. 0.001 (SD 0.002) kg/MJ; $P=0 \cdot 12$ ).

Leptin concentrations stayed significantly lower after treatment compared with baseline in the protein group (Table 3). Glucose concentrations stayed significantly lower after treatment compared with baseline in the control group. Insulin concentrations stayed significantly lower after treatment compared with baseline in both groups. $\beta$-Hydroxybutyrate, glycerol and free fatty acid concentrations returned almost to baseline values during weight regain (Table 3 ). Triacylglycerol concentrations during WM were significantly lower in the protein group than the control group.

The change in body weight of the subset of subjects (protein $n$ 31, control $n$ 39) who were also measured after 6 months follow-up is shown in Fig. 4. The analysis of the follow-up measurement of body weight showed a significant group $\times$ time interaction.

\section{Discussion}

In the present study, we investigated whether the addition of protein to the diet might limit weight regain after a weight loss of $5-10 \%$ in moderately overweight men and women. The results show that subjects who consumed $18 \%$ of their energy intake as protein regained less weight during 6 months WM $(0.8 \mathrm{~kg})$, compared with subjects who consumed $15 \%$ of their energy intake as protein $(3.0 \mathrm{~kg})$. This was independent of changes in cognitive restraint, physical activity, REE, TEE and hunger scores since these parameters did not differ between groups.

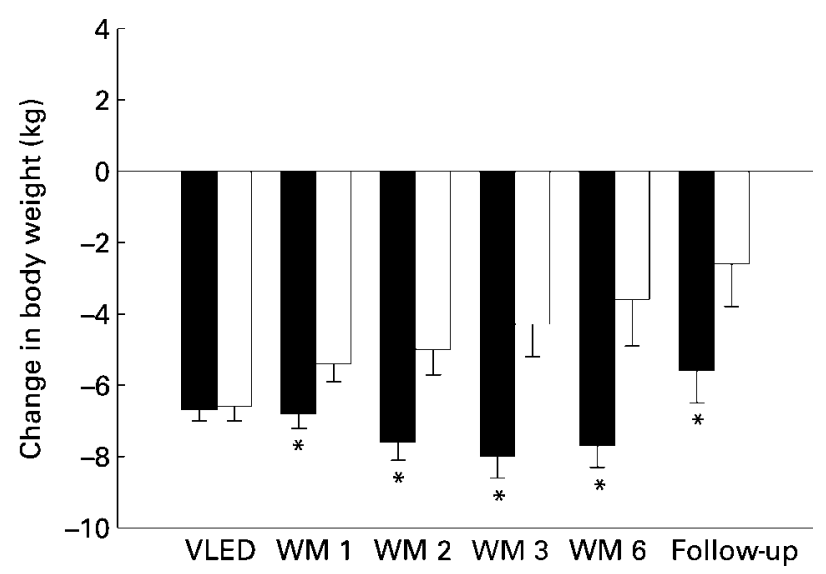

Fig. 4. The change in body weight for the subjects with follow-up in the protein group ( $\square$ ) (n 31) and the control group ( $\square$ ) (n 39) during the study compared with baseline. Values are means with standard deviations of the mean shown by vertical bars. ${ }^{\star} P<0.05$ compared with the control group. VLED, change after the very-low-energy diet period; WM 1, 2, 3, 6 change after 1, 2, 3 and 6 months weight maintenance.
The composition of the body mass regained was different for the protein and the control groups. The body mass regained in the protein group consisted only of FFM, whereas the FM still decreased during WM, which resulted in a lower percentage of body fat. In the control group, the composition of the body mass regain was FM as well as FFM. The observation that body mass regain consisting only of FFM results in a slower weight regain is in line with our hypothesis that when the composition of the weight regained consists of a greater FFM, the inevitable increase in body mass will be slower. Here, however, we have shown that this was due to increased protein intake without a change in physical activity, whereas in the study of Pasman et al. (1999), the cause appeared to be increased physical activity.

In addition to a beneficial effect of dietary protein during weight loss (Skov et al. 1999; Astrup, 2001; Dumesnil et al. 2001; Layman et al. 2003), protein also appears to support WM.

Although subjects were asked to consume $30 \mathrm{~g} / \mathrm{d}$ protein in addition to their usual diet, the analysis of the results showed a mean difference of $19 \mathrm{~g} / \mathrm{d}$ between the protein and the control group. This could imply that subjects in the protein group replaced part of their usual protein intake by the protein that was provided to them. Since this was a study under free-living conditions, the carbohydrate and fat content of the weight maintenance diet remains unknown.

With respect to satiety, we found a greater increase in postabsorptive satiety in the protein group during WM, although their energy intake did not differ significantly from that of the control group. Short-term differences in digestion, absorption and energy expenditure between different protein sources have been shown (Boirie et al. 1997; Mikkelsen et al. 2000). Boirie et al. (1997) introduced the concept of 'fast' and 'slow' proteins, based upon the differences in digestion and absorption of these proteins. These shortterm effects may be related to increases in the concentrations of gut hormones, such as glucagon-like peptide-1 (Flint et al. 1998; Gutzwiller et al. 1999; Naslund et al. 1999) and cholecystokinin (Schick et al. 1991; Burton-Freeman et al. 2002; Kissileff et al. 2003). However, this probably does not apply to post-absorptive satiety. Animal protein has been shown to introduce a higher energy expenditure (Mikkelsen et al. 2000), and, in the longer term, the higher post-absorptive satiety and thermogenesis were sustained with high-protein diets consisting of a variety of proteins from different sources (Dulloo \& Jacquet, 1999; Westerterp-Plantenga et al. 1999; Dumesnil et al. 2001; Westerterp-Plantenga et al. 2004). Moreover, a relationship between satiety and thermogenesis has been shown (Crovetti et al. 1998; Westerterp-Plantenga et al. 1999) with using high-protein diets. We therefore suggest that the higher post-absorptive satiety is due to increased thermogenesis.

The observation that the increase in REE as a function of FFM during WM did not differ significantly might be due to the lack of a significant difference in the increase of FFM.

The slower increase in RQ in the protein group reflects a more favourable body composition.

Although the treatment with respect to number of visits, measurements and attention was identical in both groups, 
there was no placebo used for the additional protein, similar to previous meal-replacement studies (Ditschuneit et al. 1999; Flechtner-Mors et al. 2000; Rothacker, 2000; Ashley et al. 2001; Allison et al. 2003). The issue of the placebo is a difficult one. It would be possible to exchange the protein drink for a carbohydrate or fat drink, but then one needs a more complete study that also addresses the specific carbohydrate and fat effect. This was beyond the scope of the present study. However, we checked whether the results in both groups could be differently related to changes in eating behaviour. The increase in cognitive restraint during the study did not differ between the protein and control group so this cannot explain the limited body weight regain during $\mathrm{WM}$ in the protein group compared with the control group. It shows that, without a difference in increase in cognitive restraint, the protein group maintained the weight loss better.

Since reporting of food intake in humans cannot be expected to be completely reliable because of reasons of privacy (Blundell, 2000), and thus often leads to incorrect conclusions (Goris \& Westerterp, 1999, 2000; Goris et al. 2000), we chose to calculate energy intake from energy expenditure and energy storage. The calculated energy intake was not significantly different between both groups and therefore cannot explain the difference in body weight regain.

Zemel (2003) showed that a low calcium intake ( $400 \mathrm{mg} / \mathrm{d})$ leads to a smaller body weight loss compared with a high calcium intake. Since the average calcium intake in the Dutch population is already rather high $(800-1600 \mathrm{mg} / \mathrm{d}$; Hulshof et al. 2003), the additional calcium intake in the protein group $(420 \mathrm{mg} / \mathrm{d})$ could have contributed to the difference in body weight regain in the present study, yet is unlikely to explain it completely.

The analysis of the follow-up measurement of body weight showed a significant difference between both groups after 3 and 6 months WM. The change in body weight over time in the control group appeared to continue as during the first 6 months, whereas the body weight over time in the protein group appeared to be maintained. Unfortunately, body composition was not determined during follow-up. This needs to be repeated in order to be able to indicate whether body composition is still a main factor in determining the difference in WM between the groups. With respect to metabolic syndrome risk factors, WM as well as waist circumference was more favourable in the protein group than in the control group.

In conclusion, a protein intake of $18 \%$ v. $15 \%$ resulted in improved WM over 6-12 months in moderately overweight subjects after a weight loss of $7.5 \%$. This improved WM implied several factors, i.e. improved body composition, fat distribution, substrate oxidation and satiety. The result suggests that improved WM is possible when it is supported multi-factorially.

\section{Acknowledgements}

We thank Ilse Nijs, Joan Senden, Wendy Sluijsmans and Loek Wouters for their contributions to the study. This study was supported by Novartis $\mathrm{CH}$, Consumer Health Ltd. (Nyon, Switzerland).

\section{References}

Allison DB, Gadbury G, Schwartz LG, Murugesan R, Kraker JL, Heshka S, Fontaine KR \& Heymsfield SB (2003) A novel soybased meal replacement formula for weight loss among obese individuals: a randomized controlled clinical trial. Eur J Clin Nutr 57, 514-522.

Anderson GH (1994) Regulation of food intake. In Modern Nutrition in Health and Disease, 8th ed. pp. 524-536 [M Shils, J Olson and M Shike, editors]. Malvern: Lea \& Febiger.

Ashley JM, St. Jeor ST, Perumean-Chaney S, Schrage J \& Bovee V (2001) Meal replacements in weight intervention. Obes Res 9, 312S-320S

Astrup A (2001) Healthy lifestyles in Europe: prevention of obesity and type II diabetes by diet and physical activity. Public Health Nutr 2B, 499-515.

Barkeling B, Rossner S \& Bjorvell H (1990) Effects of a highprotein meal (meat) and a high-carbohydrate meal (vegetarian) on satiety measured by automated computerized monitoring of subsequent food intake, motivation to eat and food preferences. Int J Obes Relat Metab Disord 14, 743-751.

Blundell JE (2000) What foods do people habitually eat? A dilemma for nutrition, an enigma for psychology. Am J Clin Nutr 71, 3-5.

Boirie Y, Dangin M, Gachon P,Vasson MP, Maubois JL \& Beaufrere B (1997) Slow and fast dietary proteins differently modulate postprandial protein accretion. Proc Nat Acad Sci USA 94, 14930-14935.

Booth DA, Chase A \& Campbell AT (1970) Relative effectiveness of protein in the late stages of appetite suppression in man. Physiol Behav 5, 1299-1302.

Burton-Freeman B, Davis PA \& Schneeman BO (2002) Plasma cholecystokinin is associated with subjective measures of satiety in women. Am J Clin Nutr 76, 659-667.

Crovetti R, Porrini M, Santangelo A \& Testolin G (1998) The influence of thermic effect of food on satiety. Eur J Clin Nutr 52, 482-488.

Ditschuneit HH, Flechtner-Mors M, Johnson TD \& Adler G (1999) Metabolic and weight-loss effects of a long-term dietary intervention in obese patients. Am J Clin Nutr 69, 198-204.

Dulloo AG \& Jacquet J (1999) Low-protein overfeeding: a tool to unmask susceptibility to obesity in humans. Int J Obes Relat Metab Disord 23, 1118-1121.

Dumesnil JG, Turgeon J, Tremblay A, et al. (2001) Effect of a lowglycaemic index-low-fat-high protein diet on the atherogenic metabolic risk profile of abdominally obese men. $\mathrm{Br} J$ Nutr 86, 557-568.

Ekelund U, Yngve A, Sjöström M \& Westerterp KR (2000) Field evaluation of the Computer Science and Application's inc. activity monitor during running and skating training in adolescent athletes. Int J Sports Med 21, 586-592.

Flechtner-Mors M, Ditschuneit HH, Johnson TD, Suchard MA \& Adler G (2000) Metabolic and weight loss effects of long-term dietary intervention in obese patients: four-year results. Obes Res 8, 399-402.

Flint A, Raben A, Astrup A \& Holst J (1998) Glucagon-like peptide 1 promotes satiety and suppresses energy intake in humans. $J$ Clin Invest 101, 515-520.

Goldstein DJ (1992) Beneficial effects of modest weight loss. Int J Obes Relat Metab Disord 16, 397-415.

Goris AHC, Meijer EP, Kester A \& Westerterp KR (2001) Use of a triaxial accelerometer to validate reported food intakes. Am J Clin Nutr 73, 549-553.

Goris AH \& Westerterp KR (1999) Underreporting of habitual food intake is explained by undereating in highly motivated lean women. $J$ Nutr 129, 878-882. 
Goris AH \& Westerterp KR (2000) Improved reporting of habitual food intake after confrontation with earlier results on food reporting. Br J Nutr 83, 363-369.

Goris AH, Westerterp-Plantenga MS \& Westerterp KR (2000) Undereating and underreporting of habitual food intake in obese men: selective underreporting of fat intake. Am J Clin Nutr 71, 130-134.

Gutzwiller JP, Drewe J, Goke B, Schmidt H, Rohrer B, Lareid V \& Beglinger C (1999) Glucagon-like peptide-1 promotes satiety and reduces food intake in patients with diabetes mellitus type 2. Am J Physiol 276, R1541-R1544.

Herman CP \& Polivy J (1980) Restrained eating. In Obesity, pp. 208-224 [AJ Stunkard, editor]. Philadelphia: WB Saunders.

Hulshof KFAM, Brussaard JH, Kruizinga AG, Telman J \& Löwik MRH (2003) Socio-economic status, dietary intake and 10y trends: the Dutch National Food Consumption Survey. Eur J Clin Nutr 57, 128-137.

Isaksson B (1980) Urinary nitrogen output as a validity test in dietary surveys. Am J Clin Nutr 33, 4-5.

Jean C, Rome S, Mathé V, Huneau JF, Aattouri N, Fromentin G, Fromentin G, Achagiotis CL \& Tome D (2001) Metabolic evidence for adaptation to a high protein diet in rats. $J$ Nutr 131, 91-98.

Kissileff HR, Carretta JC, Geliebter A \& Pi-Sunyer FX (2003) Cholecystokinin and stomach distension combine to reduce food intake in humans. Am J Physiol Regul Integr Comp Physiol 285, R992-R998.

Kramer FM, Jeffery RW, Foster JL \& Snell MK (1989) Longterm follow-up of behavioral treatment for obesity: patterns of weight regain among men and women. Int $J$ Obes Relat Metab Disord 13, 123-136.

Latner JD \& Schwartz M (1999) The effects of a high-carbohydrate, high-protein or balanced lunch upon later food intake and hunger ratings. Appetite 33, 119-128.

Layman DK, Boileau RA, Erickson DJ, Painter JE, Shine H, Santher C \& Christon DD (2003) A reduced ratio of dietary carbohydrate to protein improves body composition and blood lipid profiles during weight loss in adult women. $J$ Nutr 133, 411-417.

Mikkelsen PB, Toubro S \& Astrup A (2000) Effect of fat-reduced diets on 24-h energy expenditure: comparisons between animal protein, vegetable protein, and carbohydrate. Am J Clin Nutr 72, 1135-1141.

Naslund E, Barkeling B, King N, Gutniak M, Blundell JE, Holst JJ, Rossner S \& Hellstrom PM (1999) Energy intake and appetite are suppressed by glucagon-like peptide-1 (GLP-1) in obese men. Int $J$ Obes Relat Metab Disord 23, 304-311.

Pasman WJ, Saris WHM, Muls E, Vansant G \& Westerterp-Plantenga MS (1999) The effect of exercise training on long-term weight maintenance in weight-reduced men. Metabolism 48, $15-21$.

Pasman WJ, Westerterp-Plantenga MS, Muls E, Vansant G, Van Ree J \& Saris WHM (1997a) The effectiveness of long-term fiber supplementation on weight maintenance in weight reduced women. Int J Obes Relat Metab Disord 21, 548-555.

Pasman WJ, Westerterp-Plantenga MS \& Saris WHM (1997b) The effectiveness of long-term supplementation of carbohydrate, chromium, fiber and caffeine on weight maintenance. Int J Obes Relat Metab Disord 21, 1143-1151.
Pullar JD \& Webster AJF (1977) The energy cost of fat and protein deposition in the rat. Br J Nutr 37, 355-363.

Rothacker DQ (2000) Five-year self-management of weight using meal replacements: comparison with matched controls in rural Wisconsin. Nutrition 16, 344-348.

Schick RR, Schusdziarra V, Mossner J, Neuberger J, Schroder B, Segmuller R, Maier V \& Classen M (1991) Effect of CCK on food intake in man: physiological or pharmacological effect? $\mathrm{Z}$ Gastroenterol 29, 53-58.

Schoeller DA (1996) Hydrometry. In Human Body Composition, pp. 25-43 [AF Roche, SB Heymsfield and TG Lohmans, editors]. Champaign, IL: Human Kinetics.

Schoeller DA, Van Santen E, Peterson DW, Diez W, Jaspan J $\&$ Klein PD (1980) Total body water measurement in humans with ${ }^{18} \mathrm{O}$ and ${ }^{2} \mathrm{H}$ labeled water. Am J Clin Nutr 33, 2686-2693.

Schoffelen PFM, Westerterp KR, Saris WHM \& Ten Hoor F (1997) A dual respiration chamber with automated calibration. J Appl Physiol 83, 2064-2072.

Skov AR, Toubro S, Ronn B, Holm L \& Astrup A (1999) Randomized trial on protein vs carbohydrate in ad libitum fat reduced diet for the treatment of obesity. Int J Obes Relat Metab Disord 23, 528-536.

Stock MJ (1999) Gluttony and thermogenesis revisited. Int J Obes Relat Metab Disord 23, 1105-1117.

Stunkard AJ \& Messick S (1985) The three factor eating questionnaire to measure dietary restraint, disinhibition and hunger. J Psychosom Res 29, 71-83.

Van Gaal LF, Wauters MA \& De Leeuw IH (1997) The beneficial effects of modest weight loss on cardiovascular risk factors. Int J Obes Relat Metab Disord 21, S5-S9.

Van Marken Lichtenbelt WD, Westerterp KR \& Wouters L (1994) Deuterium dilution as a method for determining total body water: effect of test protocol and sampling time. $\mathrm{Br}$ J Nutr 72, 491-497.

Wadden TA, Foster GD \& Letizia KA (1994) One-year behavioral treatment of obesity: comparison of moderate and severe caloric restriction and the effects of weight maintenance therapy. J Consult Clin Psychol 62, 165-171.

Weir JBDV (1949) New methods for calculating metabolic rate with special references to protein metabolism. J Physiol 109, $1-9$.

Westerterp-Plantenga MS, Kempen KPG \& Saris WHM (1998) Determinants of weight maintenance in women after dietinduced weight reduction. Int J Obes Relat Metab Disord 22, $1-6$.

Westerterp-Plantenga MS, Lejeune MPGM, Nijs I, Van Ooijen M \& Kovacs EMR (2004) High protein intake sustains weight maintenance after body weight loss in humans. Int $J$ Obes Relat Metab Disord 28, 57-64.

Westerterp-Plantenga MS, Rolland V, Wilson SAJ \& Westerterp KR (1999) Satiety related to $24 \mathrm{~h}$ diet-induced thermogenesis during high protein/carbohydrate vs. high fat diets measured in a respiration chamber. Eur J Clin Nutr 53, 495-502.

Wing RR, Jeffery RW, Burton LR, Thorson C, Kuller LH \& Folsom AR (1992) Change in waist-hip ratio with weight loss and its association with change in cardiovascular risk factors. Am J Clin Nutr 55, 1086-1092.

Zemel MB (2003) Mechanisms of dairy modulation of adiposity. J Nutr 133, 252S-256S. 